\title{
Ali Seyni From spirit cult to artistic creation: The case of the genie Toula or Toulé
}

In the minds of many Nigériens, the name Toula or its variant, Toulé is not associated with the Songhay term gorou gondi. ${ }^{2}$ For educated Nigériens, or those who have access to the programmes of the national television and to the cinema, Toula or Toulé is a beautiful young girl, a theatrical and cinematographic heroine, sacrificed in order to put an end to a particularly difficult drought. Others are familiar with Toula through Boubou Hama's narratives and/or with the artistic productions inspired by them. (See Hama [1972: 169-212] for a version of the Toula legend; the film by Anna Schoering and Moustapha Alhassane and the traditional ballet mounted by the Téra Troupe.)

The situation is quite different in Songhay "country", among those who live in proximity to ponds, to the River Niger or to its tributaries. In such regions, people know that Toula, also called Toulé, is a genie, a gorou gondi, and that there are many others spirits of this type, both male and female. Traditionally, these spirits, who take the shape of water snakes, originate among the Do and the Karou, ${ }^{3}$ families which also provide the priests specialised in collective fishing and hunting of aquatic fauna (hippopotamus, crocodile, and manatee) who preside over the ceremonies honouring Dongo, the god of thunder. These priests are also referred to as Sorkos. ${ }^{4}$

But how does one become a gorou gondi? What is the process by which a human being becomes a water spirit, according to the popular beliefs of people who live on the banks of the River Niger or in the vicinity of certain ponds?

1

How does a human being become a gorou gondi? The potential elects, who, either boys or girls, can belong to the same families as the priest or Sorko. These children receive a special education in view of their possible destiny. Social representation of their status reveals a certain ambiguity. For some people, the child chosen to become a gorou gondi is a 
bonfoutou or unfortunate soul, while, in the sacred language of the cult of the water spirits, he is referred to as koyoy. But, what is a koyoy or a bonfoutou? According to popular representations, the bonfoutou is a child (boy or girl) whose father dies before his birth and whose mother dies shortly after. This double misfortune signals the possibility of a particular spiritual destiny. The bonfoutou is placed under the authority of his mother's family, in the care of his maternal uncles, to be precise. They are responsible for his upbringing. In the event that the maternal lineage decides to make a gorou gondi of the child, the elect receives a specific education and is fed a special diet. This is supposed to facilitate his metamorphosis. The diet and the training of such a child are surrounded by a ceremony to which only a small circle of initiated persons, under the authority of the maternal uncles, are privy. Although the composition of the child's diet is kept secret, people who collect incense are able to recognize the uncommon essences used to perfume the body of the elect. Finally, mention must be made of the korté ${ }^{5}$ or incantations, that only initiated persons know, for they constitute an important and highly appreciated aspect of the training of the future gorou gondi. At the end of the training period, which goes from birth to the age of six or seven, the child is placed in the hands of the chief priest and master of ceremonies and of the group of initiates in charge of his training.

The ritual bath. When the ceremony that will transform the child into a gorou a gondi is near at hand, his guides reveal the crowning elements of his education. On the day of the ceremony, the maternal uncles proceed to the water's edge (be it a pond, or river) accompanied by a group of children of the age group of the elected, bearing a black cat and a black chicken for a sacrifice. The group of children, led by a guide, is invited to bathe together. At the signal of the chief priest, the children enter the water. They are instructed to dive only once and to regain the bank immediately after. The guide must then plunge the elected child into the water during this ritual bath. Then is when the virtues of his special diet (meant to make his body slimy and slippery), of the incense and djendi or korté (incantations) come into play. If the incense and the incantations are effective, only the elected child will remain, captured by the pond or river, in which he will struggle hopelessly. Finally, he will slide to the bottom of the water, as if held by glue.

As incantations mount, the other children watch their companion struggle in vain. Then the transformation begins. The legs become a tail which the sacrificial victim (according to some) or rather the elect (in the 
minds of others), can use lift himself out of the water; from time to time the rest of the body awaits metamorphosis. When the transformation is almost completed but while the throat is still present and the tongue is not yet forked, the future spirit (genie) is able to speak to his uncles, to say to them, "Do you see me?" The uncles will answer, "Of course." Before the completion of the transformation, that is before the transformation of the head, the uncle will tell him, "Can you see us? From now on, you will have a black cat and a black chicken, alive, for your food, at each rainy season when the river swells. You may attack children belonging to the paternal lineage (they are you blood relations), but you must never attack children of the maternal lineage (they are your milk relations)." The uncles are then free to specify the victims which the gorou gondi will have the right to appropriate: a stranger, an animal (donkey, horse, cow, camel) or a new bride who runs away from her husband's house (weykoyrê).

2

Images of Toula. In the film Toula by Anna Schoering and Moustapha Alhassane and in the traditional ballet, Toulé by the Téra Troupe, it is a teenage girl who is transformed into a gorou gondi. This is neither a bonfoutou nor a koyoy, as without even mentioning her age (eighteen), the Toula in modern artistic productions does not fulfil the conditions of election mentioned earlier. We note, for example, in both the film and the ballet, that Toula's mother is alive when her daughter becomes a gorou gondi. Moreover, Toula's mother is the one who asks her daughter who has become a spirit to discriminate between her "blood relatives" and her "milk relatives", while underlining the hierarchy governing kinship ties and the consequent taboos it entails.

In the ballet, we are told that Toula's companions and the heroine herself had gone to collect firewood on the other side of the river, near the village. Toula is sent by her maternal uncle. This is how the role of the maternal uncle is mentioned. We also notice, in this version of the Toula legend that the destiny of a gorou gondi is not so exceptional as to provoke a great disturbance or situations of conflict. In fact, there is hardly any hue and cry surrounding the event. Toula's mother only starts to look for her daughter when she notices that the latter is not among the other girls who have come back to the village. The maternal uncle, a certain Biéké, tells her that Toula has been changed into a gorou gondi, He runs away. Her mother goes to the water's edge in search of her daughter and obtains from her the promise of protection of the maternal lineage. 
The film Toula takes the transformation of the oral legend even further. The author of the scenario places the action in the dramatic but not unfamiliar context of a drought. He prettifies the ceremony during which Toula is changed into a gorou gondi. In fact, she is led, to the sound of music, by a festive procession from the village to the banks of the well-known Yalambouli pond, situated in the Goroual district. Moreover, certain very pathetic elements are introduced, through a story of ill-fated love, in particular. Toula is, in the film, an exceptionally beautiful girl, who has a fiancé. Her uncle, the village chief, who has daughters of his own, for obviously political motives, sacrifices her.

Boubou Hama's Tales and Legends of Niger (Contes et Légendes du Niger) have contributed significantly to the diffusion of the name "Toula". In this type of writing, the legendary and fantastical context clearly conditions the interpretation of the genie. In fact, the genie becomes more fantastical than spiritual.

The Toula legend is divided into six short sections focusing, in turn, on the raging drought (seen as an ecological, economical and political crisis). Spiritual meanings are not emphasised. Toula's maternal uncle, the chief, is an actor of importance. The situation is presented as dramatic, exceptional and extremely pathetic, one that requires a radical cure. The latter, once decided upon is, apparently, quite unusual. Consequently, there is no mention of ritual provisions to ecological and spiritual crises of this kind. The various characters in this text are particularly individualized. Toula becomes a tragic heroine, a bonfoutou or "unfortunate" victim, and not "the elected other" or koyoy compared to whom elders and spiritual leaders take a back seat. At any rate, modern artistic productions inspired by Toula portray the latter as a heroine whose fate is uncustomary, exceptional, and pathetic. The spectator or reader is usually unaware of the fact that this exception was, in reality, part of a religious practice which, though neither commonplace nor pervasive, was nonetheless known and provided for, if only by initiated members of the society.

In his closing words, the narrator classifies the text not only as a story (conte), but, moreover, as a tale for children, which he closes with the traditional formula, in total contradiction with the prior discourse on Toula's "eternal" symbolic importance, expressed, moreover, with a certain degree of confusion.

These brief observations underline the importance of taking into consideration the contribution of elements of traditional cultures to the emergence of modern literary writing in Niger. There is invariably 
some degree of modification. But the type and meaning of such modifications are an important contribution to a proper understanding of the relationship between indigenous cultures and the mixed heritage represented by modern literary writing.

At any rate, it seems clear that artistic productions inspired from rituals of this type provide contemporary relays, but this "conservation" also involves transformation that depletes the religious nature and significance of the original cultural practice, replaced, in part by exogenous aesthetics and values.

3

Spirits in residence. In fact, the gorou gondi links the human world to the world of the spirits. These links are materialised by specific rites. But, the gorou gondi is also associated with a number of specific sites. Although Islam is currently an obstacle to the observance of the cult, there are still a number of priests in charge of the sacrifices that spiritualise these religious sites. However, a spirit is sometimes neglected when the old priest in charge of offering sacrifices dies and is not replaced, or when the priest is converted. Finally, situations of crisis in relation to water (flooding during the rainy season, when the river overflows it banks, for example) can provoke episodic relapses: the former priest, converted to Islam, often in response to family pressure, is obliged to intervene, to offer a placatory sacrifice, once again due to community pressure.

A few sites inhabited by gorou gondis. The following is not an exhaustive list. It serves to underline the fact that the Yalambouli pond, rendered famous by Boubou Hama's text and by the productions mentioned earlier, is only one of a number of sites on which sacrifices are, or were until very recently, offered to gorou gondi spirits like Toula or Toulé. Among the tributaries of the River Niger, we could mention: Youmban, Goroual, N'solo and Folcou (Dargol). Inhabited ponds include Kokorou, Kanfouley, Sébangou, Namga, Téra, Zaney, Siram and Fambita.

The table overleaf is incomplete. It presents some answers to a rapid enquiry I carried out among a few initiated persons. It indicates, where possible, the name of the site, the name or characteristics of the gorou gondi that occupies it and the name of the priest or priestess in charge.

According to our informers, the genie Toula lives at Boura and Koulikoira (see the table and the map). Popular belief has it that this genie also lives in Folcou (in the Dargol region), at N'solo, Bilow (between 


\begin{tabular}{lll} 
Site & Name or characteristics of the gorou gondi & Name of the priest or priestess \\
\hline Gouroual & Youmba & Bagouma \\
\hline Youmban & Bouloukogou & \\
\hline Folcou (Dargol) & A gorou gondi with a broken “horn” & \\
\hline Bilow (Téra) & A gorou gondi with a broken “horn" & \\
\hline Tchibaré & $\begin{array}{l}\text { A gourou gondi called “La Peule” } \\
\text { ("Fulani woman”) }\end{array}$ & \\
\hline Boura & Toula/Toulé & Hadi Koukoukou \\
\hline Koulikoira & Toula/Toulé & Hadi Koukoukou \\
\hline Kesseri & & Kimsi Kessau, Hamney Koba, \\
& & Moumouni Kimsi, \\
& & Abdou Koyoukoyo \\
\hline Kokorou & Mahama Songorizé, a blind gorou gondi & Abdou Koyolkoy \\
\hline Kanfouley & Diama Houreye & \\
\hline Namga & Houréra & \\
\hline Fambita & Assibatali & \\
\hline Siram & A gorou gondi with a ring on its lips \\
\hline
\end{tabular}

the dam and the first bridge at Téra), at Tchibaré, in the Dargol region (Gayanga, Salmey-koum). Some people also mention Galbil, Koubou, Kassim (Kouboutchiré), Adidji Bera, Goron, Deyyey, Koguissiké, Kountoukoum (Boulam), Tondi Bangou (Kossa). It is interesting to note that the gorou gondi sometimes deserts its place of abode upon the death of its priest or priestess. It is the duty of the new priest or priestess to go in search of the gorou gondi in his or her care, mounted on a black donkey.

In conclusion: on the belief in gorou gondi. As in any other type of belief, this is a question of faith. From the standpoint of the populations concerned, this belief and the ceremonies related to it are neither banal nor meaningless. They are clearly related to a certain conception of nature, of climatic phenomena and of the place human beings occupy in world that opens unto the realm of the spirits on whom they also depend. Artistic productions simultaneously conserve, transform and deform such beliefs. Although some of these ancestral beliefs are currently eroded by the influence of revealed religions like Islam or Christianity, there are, however still a few remaining pockets of resistance in which the cults of the spirits and traditional beliefs are observed. Until when? No one knows. 


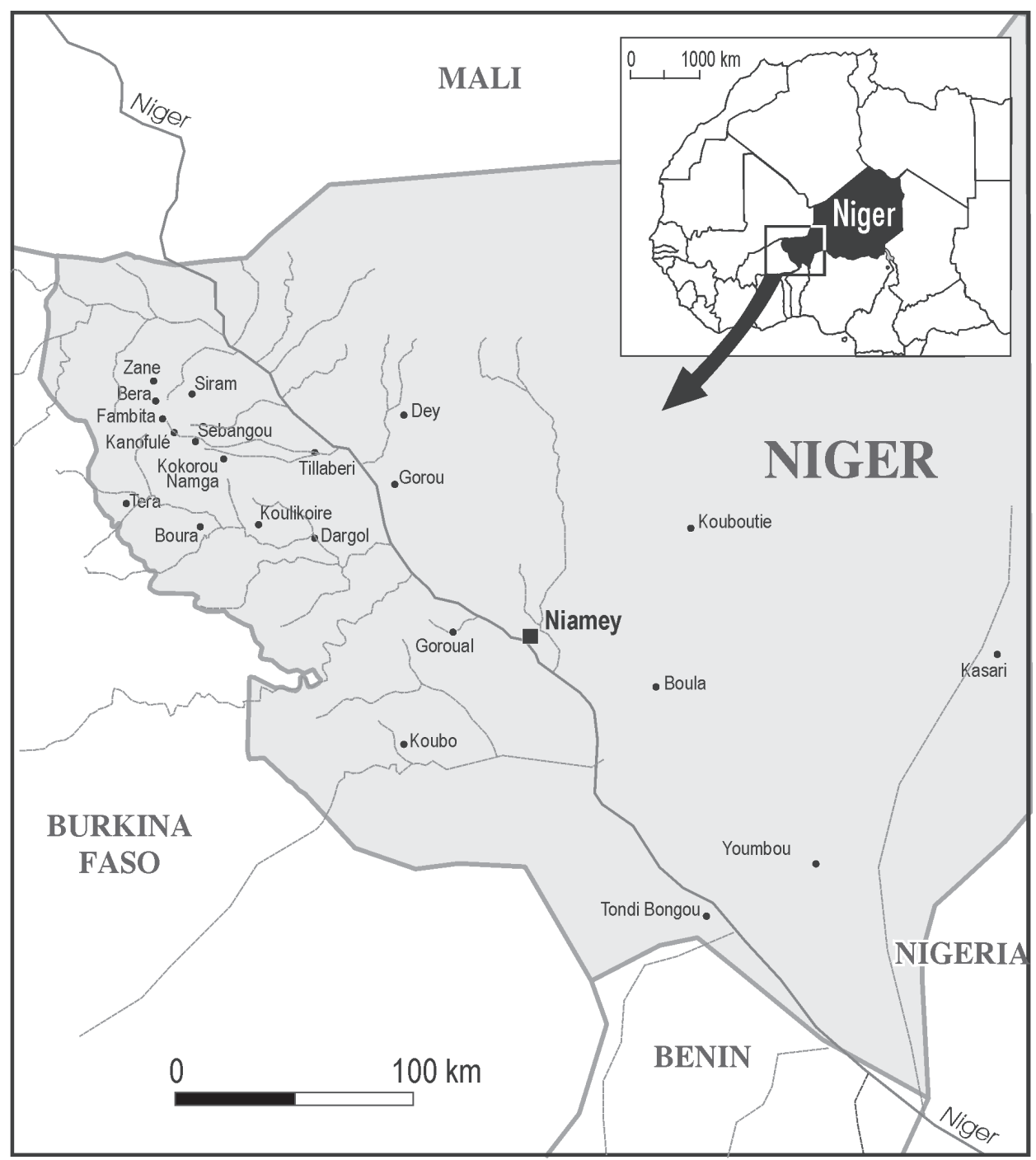

THE NIGER RIVER BASIN - SITES INHABITED BY GOROU GONDIS

\section{Acknowledgements}

My thanks to Hama Younoussi, called Koda; Moussa Mazou and to Adamou Issifi called Kodo who helped me by sharing their knowledge on the gorou gondi.

\section{Notes}

1. Ali Seyni (1938-2004) served Niger in many capacities. He was civil engineer, a professor, a civil servant, a member of parliament, a councillor to the Prime Minister, an advisor to several international agencies and a former mayor of Niamey. He also had a wide-ranging interest in indigenous culture and oral traditions. He made this presentation - "a report from the field" - at a workshop "Myths, Definitions, Approaches and Practices" organised by the interdisciplinary research group on "Literature, Gender and Development. Visions and Perspectives from Niger" at the University 
Abdou Moumouni of Niamey, Niger held on 3-4 January 2004. He died before its final preparation for this volume. We publish the paper with the permission of his family. The editor edited his draft paper and added the endnotes and bibliography.

2. Literally, "pond snake", the gorou gondi does not belong to the biological realm, but to the spiritual universe of the hari zinni, or water spirits (genies).

3. The Do and the Karou are magicians responsible for the cult of water spirits. Their supremacy has been displaced by the introduction of dances of possession, holley. Their rituals existed prior to Islam and to holley. Each Do or Karou is responsible for a given pond or tributary and for the spirit that lives there (see Olivier de Sardan, 1982: 120).

4. In the Songhay-Zarma language, the term Sorko designates a fisherman, whether the ordinary professional or the master-fisherman whose knowledge is "handed down from father to son". The term is used here in the second sense. According to Olivier de Sardan, (1982: 341-342) certain Sorkos take part in dances of possession, holley, during which they recite the formulae of Dongo, the god of thunder and those of the genies belonging to the Tooru family, especially during ceremonies organized to pray for rain (yenendi). Many of these Sorkos involved in spirit possession no longer practice fishing. They retain an essentially "symbolic or magical knowledge" (see Stoller quoted in Olivier de Sardan, 1982: 342).

5. The korté or kotté is a "magical charm", or "magical formula" which deflects an evil spell or makes a wish come true. It can be a word, a formula or a magical object. The korté or kotté is not to be confused with Islamic practices or "western prescriptions". It is linked to artisanal professions and to specialized, secret knowledge (Olivier de Sardan, 1982: 342).

\section{Bibliography}

Hama, Boubou. 1966. Histoire traditionnelle d'un peuple: les Zarma-Songhay. Paris, Présence Africaine. . 1972. Contes et Légendes du Niger (Tome 1). Paris: Présence Africaine.

Olivier de Sardan, Jean-Pierre. 1982. Concepts et Conceptions Songhay-Zarma. Histoire, Culture, Société. Paris: Ed. Nubia.

Rouch, Jean. 1960. La Religion et la magie songhay. Paris: Presses Universitaires de France.

Stoller, P. 1978. The Word and the Cosmos: "Zarma ideology revisited". Dakar, Bull. IFAN 40 (4): 863-878. 